University of Nebraska - Lincoln

DigitalCommons@University of Nebraska - Lincoln

Agronomy \& Horticulture -- Faculty Publications

Agronomy and Horticulture Department

$12-1969$

\title{
Sweetclover Weevil Feeding Stimulants: Isolation and Identification of Glucose, Fructose, and Sucrose
}

\author{
W. R. Akeson \\ H. J. Gorz \\ Francis A. Haskins \\ University of Nebraska-Lincoln, fhaskins@neb.rr.com
}

Follow this and additional works at: https://digitalcommons.unl.edu/agronomyfacpub

Part of the Plant Sciences Commons

Akeson, W. R.; Gorz, H. J.; and Haskins, Francis A., "Sweetclover Weevil Feeding Stimulants: Isolation and Identification of Glucose, Fructose, and Sucrose" (1969). Agronomy \& Horticulture -- Faculty Publications. 296.

https://digitalcommons.unl.edu/agronomyfacpub/296

This Article is brought to you for free and open access by the Agronomy and Horticulture Department at DigitalCommons@University of Nebraska - Lincoln. It has been accepted for inclusion in Agronomy \& Horticulture -Faculty Publications by an authorized administrator of DigitalCommons@University of Nebraska - Lincoln. 


\title{
Sweetclover Weevil Feeding Stimulants: Isolation and Identification of Glucose, Fructose, and Sucrose ${ }^{1}$
}

\author{
W. R. Akeson, H. J. Gorz, and F. A. Haskins ${ }^{2}$
}

\section{ABSTRACT}

The water-soluble fraction of Melilotus leaves previously referred to as Stimulant $A$ was further fractionated by preparative paper chromatography into three factors, each having a stimulatory effect on sweetclover weevil feeding. The three factors, designated Stimulant $\mathbf{A}_{1}, \mathbf{A}_{2}$ and $A_{3}$, were identified as sucrose, glucose, and fructose, respectively, by co-chromatography with known sugars on cellulose-coated thin-layer plates. Silver nitrate, anisidine phthalate, and anthrone were employed as detection agents. The isolated compounds and corresponding reagent grade sugars were identical in chromatographic and chemical behavior, as well as in feeding stimulant activity. Sucrose stimulated the greatest amount of feeding when the three sugars were compared at equal concentration in the same bioassay. Disks treated with glucose and fructose were fed upon equally at the three concentrations tested. Although these sugars probably play a significant role in the mechanism of resistance and susceptibility of Melilotus plants to weevil feeding, it is not likely that they are wholly responsible for the host specificity displayed by the sweetclover weevil.

Additional index words: Sitona cylindricollis, Melilotus officinalis, Melilotus infesta.

A

water-soluble factor derived from Melilotus leaves stimulates feeding by the adult sweetclover weevil, Sitona cylindricollis (Fahraeus) (1, 3). The active fraction was separated by preparative paper chromatography of hot water extracts and detected by means of a bioassay (4) which permit determination of the extent of weevil feeding on washed disks of sweetclover root tissue impregnated with the fraction to be tested. The stimulant, designated Stimulant $A$, was found to occur in plants of $M$. infesta Guss. as well as in $M$. officinalis (L.) Lam., species that are resistant and susceptible, respectively, to weevil feeding (7). Results obtained with the semi-quantitative bioassay suggested that young leaves of the two species were sufficiently similar in content of Stimulant A to rule out the possibility that the resistance of $M$. infesta was due primarily to lack of this feeding stimulant (3). The further separation of Stimulant A into three distinct components, each with feeding stimulant activity, and their subsequent isolation and identification, are described in the present report.

${ }^{1}$ Contribution from the Nebraska Agricultural Experiment Station, Lincoln, Nebraska, and the Crops Research Division, Agricultural Research Service, U. S. Department of Agriculture. Supported in part by Crops Research Division and Entomology Research Division, Agric. Res. Serv., USDA Grant No. 12-14. 100-8027 (33). Published with the approval of the Director as Paper No. 2560, Journal Series, Nebraska Agr. Exp. Sta. Received May 26, 1969.

"Assistant Professor of Agronomy, University of Nebraska; Research Geneticist, Crops Research Division, Agricultural Re search Service, U. S. Department of Agriculture; and Bert Rodgers Professor of Agronomy, University of Nebraska, respectively, Lincoln, Nebraska, 68503. The technical assistance of Patricia Underwood and Henry J. Stevens is gratefully acknowledged.

\section{MATERIALS AND METHODS}

Freshly harvested young leaves of field-grown $M$. officinalis var. 'Goldtop' plants were weighed, washed with distilled water, dropped into boiling water (5 $\mathrm{ml} / \mathrm{g}$ of fresh tissue), and autoclaved for $20 \mathrm{~min}$ at $1.1 \mathrm{~kg} / \mathrm{sq} \mathrm{cm}$. After removal of the leaf material, the extract was frozen and lyophilized to dryness. The powder obtained was stored at $-20 \mathrm{C}$ until used.

Solutions for chromatography were prepared by dissolving the dried powder in water such that approximately $0.75 \mathrm{ml}$ of the final solution represented $1 \mathrm{~g}$ of the original fresh tissue. Ascending chromatography for the separation of feeding stimulants was accomplished essentially as described by Akeson et al. $(1,3)$, except that different solvents were used. Chromatograms were cut into horizontal strips at widths previously determined to be suitable for separating the stimulant factors, and each strip was eluted with water. Eluates were tested for stimulant activity by means of the previously described bioassay procedure (4).

Partial purification of crude extracts was effected by chromatographing with Solvent I (isopropyl alcohol, ammonium hydroxide, water, $8: 1: 2, \mathrm{v} / \mathrm{v} / \mathrm{v}$ ). The eluate from the single band containing most of the stimulant activity was rechromatographed with Solvent II (chloroform, acetic acid, water, 4:4:1, v/v/v). Eluates from the two bands containing stimulant activity were applied to separate chromatograms and developed with five successive passes of Solvent III (ethyl acetate, isopropyl alcohol, water, 65:38:17, v/v/v). Chromatograms were air dried between solvent passes. Finally eluates containing the three partially purified feeding stimulants were separately rechromatographed with five passes of Solvent III. On each of these final chromatograms, activity was confined essentially to a single band. Elution of the active bands yielded the three purified feeding stimulants, designated Stimulants $A_{1}, A_{2}$, and $A_{3}$ (in order of increasing $R f$ in Solvent III), which were used in further studies.

Stimulants $A_{1}, A_{2}$, and $A_{3}$ were tentatively identified as sugars on the basis of their reaction to the phenol sulfuric acid and anthrone tests (6). The phenol sulfuric acid test was used to determine the sugar content of the final eluates and concentrations were adjusted as needed for subsequent tests.

The identity and homogeneity of the three purified stimulants were determined by co-chromatography with known mono- and disaccharides on $20 \times 20 \mathrm{~cm}$ cellulose-coated thin-layer plates. The chromatograms consisted of a $0.3-\mathrm{mm}$ layer of MN cellulose powder applied to glass plates as a water slurry (15 g cellulose in $90 \mathrm{ml}$ water). Spots of the solutions to be chromatographed were applied to the air-dried plates along a line $2.5 \mathrm{~cm}$ from one edge of the plate. Concentration of all solutions was $1 \%$ and aliquots of approximately $2 \mu \mathrm{l}$ were chromatographed. Solvent ascent was $15 \mathrm{~cm}$ above the base line. Silver nitrate, anisidine phthalate, and anthrone reagents were used for the detection of sugars on the chromatograms. Chromatograms dipped for $1 \mathrm{~min}$ in silver nitrate solution ( $5 \mathrm{ml}$ saturated silver nitrate solution in $25 \mathrm{ml}$ water added to $1000 \mathrm{ml}$ acetone) were subsequently sprayed with ethanolic $0.5 \mathrm{~N}$ sodium hydroxide and then with aqueous $5 \%$ sodium thiosulfate for the detection of reducing compounds (8). Other chromatograms sprayed with anisidine phthalate $\{p$-anisidine $(0.1 M)$ and phthalic acid $(0.1$ $M)$ in $96 \%$ ethanol $\}$ were heated for $5 \mathrm{~min}$ at $100 \mathrm{C}$ for the identification of aldopentoses (red) and aldohexoses (yellow). Ketohexoses developed a yellow color after being heated at 100 C for $20 \mathrm{~min}(8)$. Anthrone reagent $(0.3 \mathrm{~g}$ anthrone in $10 \mathrm{ml}$ glacial acetic acid, $20 \mathrm{ml}$ ethanol, $3 \mathrm{ml} 85 \%$ phosphoric acid, and $1 \mathrm{ml}$ water) was used to detect ketohexoses or mixtures of sugars containing ketohexoses (dark yellow), and sugar alcohols (white on light-yellow background) (10). Colors were developed by heating the anthrone-treated chromatograms at 100 C for $12 \mathrm{~min}$.

After each of the three stimulants had been identified, the biological activity of the isolated compound was compared with that of the corresponding reagent grade sugar by means of the bioassay procedure (4). Separate comparisons were made of each stimulant and the corresponding sugar at three concentrations 
$(0.1,0.3$, and $0.9 \%, w / v$ with water as a control. Each comparison consisted of five disks per treatment, seven treatments (two compounds, three concentrations of each, plus a control) in each feeding chamber, a population of three weevils per disk, and four replications. A mixture of $0.1 \mathrm{ml}$ of the sugar solution being tested plus $0.05 \mathrm{ml}$ of water was applied to the five disks of each treatment.

In another test equal concentrations of the reagent grade sugars corresponding to Stimulants $A_{1}, A_{2}$, and $A_{3}$ were compared by the procedure described above except that each comparison consisted of four treatments (three sugars at equal concentration plus a water control). Three concentration levels were assayed in three separate comparisons.

\section{RESULTS AND DISCUSSION}

The association of feeding stimulant activity with various bands during the stepwise chromatographic purification of Stimulants $A_{1}, A_{2}$, and $A_{3}$ is shown in Table 1. Initial fractionation of the crude hot water extract with Solvent I gave a single eluate (from Band 3) which had significant stimulant activity (Table 1, Step A). Rechromatography of the eluate from Band 3 with Solvent II resulted in the appearance of activity in Bands 3 and 4 (Step B). The feeding stimulant activity in Band 3 was about twice as great as that in Band 4. The location of the two active bands coincided with two separated bands that became visible when chromatograms developed with Solvent II were treated with silver nitrate or anisidine phthalate. These observations clearly indicated that the factor designated as Stimulant $\mathrm{A}$ in previous work $(1,3)$ actually consisted of two or more factors.

When the eluate from Band 3 (Step B) was rechromatographed with Solvent III, the activity was again fractioned into two major bands (Step C, Bands 2 and 3). Although there was appreciable activity in Band

Table 1. Chromatographic purification of three feeding stimulants from a hot-water extract of $M$. officinalis leaves.

\begin{tabular}{|c|c|c|c|c|c|c|}
\hline Step & $\begin{array}{l}\text { Fxtract } \\
\text { or eluate } \\
\text { chromato- } \\
\text { graphed* }\end{array}$ & $\begin{array}{c}\text { Sol } \\
\text { vent } \\
\text { no. }\end{array}$ & $\begin{array}{c}\text { Bandl } \\
\text { no. }\end{array}$ & $\begin{array}{c}\text { Band } \\
\operatorname{limits} \neq \\
\left(R_{f}\right)\end{array}$ & $\begin{array}{c}\text { \% disk area } \\
\text { consumeds } \\
\text { Mean } \pm \mathrm{SE}\end{array}$ & $\begin{array}{c}\text { Stimu- } \\
\text { lant }\end{array}$ \\
\hline $\bar{A}$ & Crude & I & $\begin{array}{l}1 \\
2 \\
3 \\
4 \\
5 \\
6\end{array}$ & $\begin{array}{l}0.00-0.17 \\
0.17-03.7 \\
0.37-0.40 \\
0.50-0.67 \\
0.67-0.83 \\
0.83-1.00\end{array}$ & $\begin{array}{r}1.2 \pm 0.6 \\
7.1 \pm 2.2 \\
42.4 \pm 3.0 \\
1.6 \pm 0.7 \\
0.8 \pm 0.7 \\
0.3 \pm 0.3\end{array}$ & \\
\hline B & $A-3$ & II & $\begin{array}{l}1 \\
2 \\
3 \\
4 \\
5 \\
6\end{array}$ & $\begin{array}{l}0.00-0.13 \\
0.13-0.25 \\
0.25-0.40 \\
0.40-0.52 \\
0.52-0.75 \\
0.75-1.00\end{array}$ & $\begin{array}{r}0.2 \pm 0.1 \\
0.0 \pm 0.0 \\
53.9 \pm 5.8 \\
27.4 \pm 2.2 \\
0.5 \pm 0.3 \\
1.0 \pm 0.5\end{array}$ & \\
\hline $\mathrm{c}$ & $\mathrm{B}-3$ & III & $\begin{array}{l}1 \\
2 \\
3 \\
4 \\
5 \\
6\end{array}$ & $\begin{array}{l}0.00-0.13 \\
0.13-02.6 \\
0.26-0.37 \\
0.37-0.47 \\
0.47-0.74 \\
0.74-1.00\end{array}$ & $\begin{array}{r}5.0 \pm 1.5 \\
63.5 \pm 4.7 \\
40.8 \pm 4.9 \\
27.7 \pm 4.6 \\
6.3 \pm 2.9 \\
3.2 \pm 1.6\end{array}$ & $\begin{array}{l}A_{1} \\
A_{2}\end{array}$ \\
\hline D & $B-4$ & III & $\begin{array}{l}1 \\
2 \\
3 \\
4 \\
5 \\
6\end{array}$ & $\begin{array}{l}0.00-0.13 \\
0.13-0.26 \\
0.26-0.35 \\
0.35-0.47 \\
0.47-0.74 \\
0.74-1.00\end{array}$ & $\begin{array}{r}4.2 \pm 2.6 \\
12.0 \pm 2.8 \\
20.5 \pm 3.8 \\
47.0 \pm 5.8 \\
2.5 \pm 1.7 \\
3.8 \pm 1.8\end{array}$ & $\mathrm{~A}_{3}$ \\
\hline$E$ & $\mathrm{C}_{-2}$ & III & $\begin{array}{l}2 \\
3 \\
4\end{array}$ & $\begin{array}{l}0.13-0.27 \\
0.27-0.37 \\
0.37-0.50\end{array}$ & $\begin{array}{r}49.8 \pm 5.9 \\
10.2 \pm 2.4 \\
7.2 \pm 3.6\end{array}$ & $A_{1}$ \\
\hline $\mathrm{F}$ & $C-3$ & III & $\begin{array}{l}2 \\
3 \\
4\end{array}$ & $\begin{array}{l}0.13-0.27 \\
0.27-0.37 \\
0.37-0.50\end{array}$ & $\begin{aligned} 2.0 & \pm 0.7 \\
29.7 & \pm 3.0 \\
4.7 & \pm 2.1\end{aligned}$ & $\mathrm{~A}_{2}$ \\
\hline $\mathrm{G}$ & D -4 & III & $\begin{array}{l}2 \\
3 \\
4\end{array}$ & $\begin{array}{l}0.13-0.27 \\
0.27-0.37 \\
0.37-0.50\end{array}$ & $\begin{array}{r}5.3 \pm 2.4 \\
10.0 \pm 3.8 \\
42.8 \pm 5.1\end{array}$ & $A_{3}$ \\
\hline
\end{tabular}

* Refers to the step and band, respectively, from which the eluate was obtatned for rechromatography. † Solvent I: isopropyl alcohol, ammonium hydroxtde, water (8:1:2, $\mathrm{v} / \mathrm{v} / \mathrm{v})$; Solvent II; chloroform, acetic acid, water $(4: 4: 1, \mathrm{v} / \mathrm{v} / \mathrm{v})$; Solvent UI: ethyl acetate, isopropyl alcohol, water $(65: 38: 17, v / v / v$, five solvent passes). \$ Solven ascent of $15 \mathrm{~cm}$ on $18.5 \times 28.5 \mathrm{~cm}$ sheets or Whatman No. 3 fiter paper. $\$$ Bands from tho chr the each mean ts the average of 10 observations. A population of three weevils per disk tween steps.
4 (Step G), additional work revealed that the activity was due to a mixture of Stimulants $\mathrm{A}_{2}$ and $\mathrm{A}_{3}$. Therefore, no further work was done with this fraction. The eluates from Band 2 (designated Stimulant $A_{1}$ ) and Band 3 (designated Stimulant $\mathrm{A}_{2}$ ) were chromatographed a second time with Solvent III and in each case, the major activity was now confined to the respective band from which the eluate originated (Band 2 in Step E; Band 3 in Step F).

Rechromatography of the eluate from Band 4 (Step B) with Solvent III resulted in the appearance of most of the stimulant activity in Band 4 (Step D), with some activity also present in Bands 2 and 3. The latter two bands were subsequently found to contain small amounts of Stimulants $A_{1}, A_{2}$, and $A_{3}$; therefore, no further work was done with these bands. When the eluate from Band 4 (Step D), which was designated Stimulant $\Lambda_{3}$, was chromatographed a second time with Solvent III, the activity was essentially confined to Band 4 (Step G).

Thin-layer chromatography of Stimulants $\mathbf{A}_{1}, \mathbf{A}_{2}$, and $A_{3}$ on cellulose-coated plates gave single spots for each stimulant with the nine solvent systems listed in Table 2. These data provide additional evidence that each of the three stimulants is a single compound, distinct from the other two stimulants.

The three stimulants were identified by co-chromatography with known sugars on cellulose-coated thinlayer plates (Table 2.) Nine different solvent systems and three detection agents were used. Stimulant $A_{1}$ had $\mathbf{R}_{\mathbf{f}}$ values identical to those of sucrose. Neither compound reacted with silver nitrate or anisidine pthalate; both turned yellow when treated with anthrone reagent, which is the characteristic reaction of ketoses and ketose-containing compounds. Stimulant $A_{2}$ and glucose had identical $R_{f}$ values. Both reacted with silver nitrate, as is characteristic of reducing compounds. Neither gave a positive reaction with anthrone reagent, but anisidine phthalate treatment produced a yellow color after heating for $5 \mathrm{~min}$, indicating the presence of an aldohexose. Stimulant $A_{3}$ had $R_{\mathbf{f}}$ values corresponding to those of fructose, as well as identical reactions with silver nitrate (positive), anthrone reagent (positive), and anisidine phthalate (negative with 5 min heating but positive with 20 min heating). Based on the data presented in $\mathbf{T a}$ ble 2, Stimulant $A_{1}$ was identified as sucrose, Stimulant $A_{2}$ as glucose, and Stimulant $A_{3}$ as fructose.

Comparisons of the feeding-stimulant activities of the isolated compounds with those of the corresponding reagent grade sugars are presented in Table 3. The solutions assayed contained $0.1,0.3$, and $0.9 \%$ $(\mathrm{w} / \mathrm{v})$ of sugar and provided approximately 20,60, and $180 \mu \mathrm{g}$, respectively, of sugar in each bioassay disk. At each concentration, the feeding value of the isolated compound was nearly identical to that of the corresponding known sugar. These results provide critical evidence that the isolated stimulants and corresponding reagent grade sugars are identical in biological activity as well as in chromatographic and chemical behavior. Under the conditions employed in the bioassays, the response of the weevils to concentration differences was most sensitive for fructose and least sensitive for glucose.

When a direct comparison was made of the relative feeding stimulant activities of glucose, fructose, and 
Table 2. Chromatography of Stimulants $A_{1}, A_{2}$, and $A_{3}$, and reagent grade sugars on $20 \times 20 \mathrm{~cm}$ cellulose-coated thin-layer plates in nine solvent systems, and reaction of spots with three detection agents.

\begin{tabular}{|c|c|c|c|c|c|c|c|c|c|c|c|c|c|}
\hline \multirow[b]{3}{*}{ Sugar } & \multicolumn{9}{|c|}{ Rf values (15-cm ascent) in nine solvent systems* } & \multicolumn{4}{|c|}{ Reaction with detection agent +} \\
\hline & \multirow{2}{*}{$\begin{array}{l}\text { Water- } \\
\text { sat. } \\
\text { phenol }\end{array}$} & \multirow{2}{*}{$\begin{array}{c}8 \mathrm{Chl} \\
8 \mathrm{MeOH} \\
1 \mathrm{H}_{2} \mathrm{O}\end{array}$} & \multirow{2}{*}{$\begin{array}{l}16 \mathrm{Chl} \\
16 \mathrm{HAc} \\
3 \mathrm{H}_{2} \mathrm{O} \\
\end{array}$} & \multirow{2}{*}{$\begin{array}{l}8 \mathrm{EtAc} \\
2 \mathrm{Pyr} \\
1 \mathrm{H}_{2} \mathrm{O}\end{array}$} & \multirow{2}{*}{$\begin{array}{l}65 \mathrm{EtAc} \\
23 \mathrm{i}-\mathrm{PrOH} \\
12 \mathrm{H}_{2} \mathrm{O}(5)\end{array}$} & \multirow{2}{*}{$\begin{array}{c}2 \mathrm{n}-\mathrm{BuOH} \\
1 \mathrm{HAO} \\
1 \mathrm{H}_{2} \mathrm{O}\end{array}$} & \multirow{2}{*}{$\begin{array}{c}3 \mathrm{n}-\mathrm{BuOH} \\
1 \mathrm{Pyr} \\
1 \mathrm{H}_{2} \mathrm{O}\end{array}$} & \multirow{2}{*}{$\begin{array}{l}4 \mathrm{n}-\mathrm{BuOH} \\
5 \mathrm{acetone} \\
1 \mathrm{H}_{2} \mathrm{O}(3) \ddagger .\end{array}$} & \multirow{2}{*}{$\begin{array}{c}5 \mathrm{n}-\mathrm{BuOH} \\
31-\mathrm{PrOH} \\
2 \mathrm{H}_{2} \mathrm{O} \\
\end{array}$} & \multirow[b]{2}{*}{$\begin{array}{l}\text { Silver } \\
\text { nitrate }\end{array}$} & \multirow{2}{*}{\multicolumn{2}{|c|}{$\frac{\text { Anisidine phthalate }}{\text { Heat, min }}$}} & \multirow[b]{2}{*}{$\begin{array}{c}\text { Anthrone } \\
\text { reagent }\end{array}$} \\
\hline & & & & & & & & & & & & & \\
\hline $\begin{array}{l}\text { Sttm. } A_{1} \\
\text { Stim. } A_{2} \\
\text { Stim. } A_{3}\end{array}$ & $\begin{array}{l}0.58 \\
0.53 \\
0.63\end{array}$ & $\begin{array}{l}0.20 \\
0.31 \\
0.40\end{array}$ & $\begin{array}{l}0.35 \\
0.34 \\
0.46\end{array}$ & $\begin{array}{l}0.03 \\
0.10 \\
0.12\end{array}$ & $\begin{array}{l}0.14 \\
0.29 \\
0.37\end{array}$ & $\begin{array}{l}0.49 \\
0.55 \\
0.61\end{array}$ & $\begin{array}{l}0.30 \\
0.37 \\
0.43\end{array}$ & $\begin{array}{l}0.27 \\
0.36 \\
0.49\end{array}$ & $\begin{array}{l}0.27 \\
0.33 \\
0.37\end{array}$ & $\begin{array}{l}- \\
+ \\
+\end{array}$ & $\overline{\mathrm{Y}}$ & $\begin{array}{l}\overline{\mathrm{Y}} \\
\mathrm{Y}\end{array}$ & $\begin{array}{l}Y \\
\bar{Y}\end{array}$ \\
\hline $\begin{array}{l}\text { Ribose } \\
\text { Xylose } \\
\text { Arabinose }\end{array}$ & $\begin{array}{l}0.71 \\
0.58 \\
0.66\end{array}$ & $\begin{array}{l}\mathbf{0 . 5 5} \\
0.48 \\
0.44\end{array}$ & $\begin{array}{l}0.51 \\
0.41 \\
0.46\end{array}$ & $\begin{array}{l}0.30 \\
0.20 \\
0.15\end{array}$ & $\begin{array}{l}0.69 \\
0.50 \\
0.43\end{array}$ & $\begin{array}{l}0.66 \\
0.63 \\
0.61\end{array}$ & $\begin{array}{l}0.52 \\
0.49 \\
0.42\end{array}$ & $\begin{array}{l}0.65 \\
0.53 \\
0.48\end{array}$ & $\begin{array}{l}0.45 \\
0.40 \\
0.37\end{array}$ & $\begin{array}{l}+ \\
+ \\
+\end{array}$ & $\begin{array}{l}\mathrm{R} \\
\mathrm{R} \\
\mathrm{R}\end{array}$ & $\begin{array}{l}\mathrm{R} \\
\mathrm{R} \\
\mathrm{R}\end{array}$ & - \\
\hline $\begin{array}{l}\text { Mannose } \\
\text { Galactose } \\
\text { Glucose }\end{array}$ & $\begin{array}{l}0.58 \\
0.57 \\
0.53\end{array}$ & $\begin{array}{l}0.36 \\
0.28 \\
0.31\end{array}$ & $\begin{array}{l}0.36 \\
0.31 \\
0.33\end{array}$ & $\begin{array}{l}0.12 \\
0.07 \\
0.09\end{array}$ & $\begin{array}{l}0.37 \\
0.25 \\
0.29\end{array}$ & $\begin{array}{l}0.59 \\
0.53 \\
0.55\end{array}$ & $\begin{array}{l}0.44 \\
0.33 \\
0.37\end{array}$ & $\begin{array}{l}0.43 \\
0.27 \\
0.36\end{array}$ & $\begin{array}{l}0.39 \\
0.33 \\
0.33\end{array}$ & $\begin{array}{l}+ \\
+ \\
+\end{array}$ & $\begin{array}{l}\mathbf{Y} \\
\mathbf{Y} \\
\mathbf{Y}\end{array}$ & $\begin{array}{l}\mathbf{Y} \\
\mathbf{Y} \\
\mathbf{Y}\end{array}$ & $\overline{-}$ \\
\hline $\begin{array}{l}\text { Sorbose } \\
\text { Fructose }\end{array}$ & $\begin{array}{l}0.55 \\
0.64\end{array}$ & $\begin{array}{l}0.36 \\
0.40\end{array}$ & $\begin{array}{l}0.39 \\
0.47\end{array}$ & $\begin{array}{l}0.13 \\
0.12\end{array}$ & $\begin{array}{l}0.35 \\
0.37\end{array}$ & $\begin{array}{l}0.59^{\circ} \\
0.61\end{array}$ & $\begin{array}{l}0.41 \\
0.43\end{array}$ & $\begin{array}{l}0.44 \\
0.49\end{array}$ & $\begin{array}{l}0.35 \\
0.37\end{array}$ & + & - & $\begin{array}{l}\mathbf{Y} \\
\mathbf{Y}\end{array}$ & $\begin{array}{l}\mathrm{Y} \\
\mathrm{Y}\end{array}$ \\
\hline $\begin{array}{l}\text { Sucrose } \\
\text { Maltose }\end{array}$ & $\begin{array}{l}0.58 \\
0.51\end{array}$ & $\begin{array}{l}0.20 \\
0.12\end{array}$ & $\begin{array}{l}0.35 \\
0.14\end{array}$ & $\begin{array}{l}0.03 \\
0.02\end{array}$ & $\begin{array}{l}0.14 \\
0.08\end{array}$ & $\begin{array}{l}0.49 \\
0.41\end{array}$ & $\begin{array}{l}0.30 \\
0.24\end{array}$ & $\begin{array}{l}0.27 \\
0.19\end{array}$ & $\begin{array}{l}0.27 \\
0.17\end{array}$ & $\bar{t}$ & $\overline{\mathrm{Y}}$ & $\bar{Y}$ & $\begin{array}{l}\mathrm{Y} \\
-\end{array}$ \\
\hline $\begin{array}{l}\text { Xylitol } \\
\text { Arabitol } \\
\text { Mannitol }\end{array}$ & $\begin{array}{l}0.66 \\
0.67 \\
0.57\end{array}$ & $\begin{array}{l}0.41 \\
0.62 \\
0.29\end{array}$ & $\begin{array}{l}0.57 \\
0.55 \\
0.48\end{array}$ & $\begin{array}{l}0.11 \\
0.13 \\
0.08\end{array}$ & $\begin{array}{l}0.40 \\
0.42 \\
0.31\end{array}$ & $\begin{array}{l}0.65 \\
0.66 \\
0.59\end{array}$ & $\begin{array}{l}0.41 \\
0.43 \\
0.35\end{array}$ & $\begin{array}{l}0.47 \\
0.51 \\
0.32\end{array}$ & $\begin{array}{l}0.39 \\
0.40 \\
0.36\end{array}$ & $\begin{array}{l}t \\
+\end{array}$ & - & - & $\begin{array}{l}w \dagger \\
w \\
w\end{array}$ \\
\hline
\end{tabular}

Table 3. Comparison of the feeding stimulant activity of Stimulants $A_{1}, A_{3}$, and $A_{3}$ with reagent grade sucrose, glucose and fructose, respectively. Each comparison consisted of five disks per treatment, seven treatments in each replication, a population of three weevils per disk, and four replications.

\begin{tabular}{|c|c|c|c|c|}
\hline \multicolumn{2}{|c|}{$\begin{array}{l}\text { Solutions } \\
\text { compared* }\end{array}$} & \multicolumn{3}{|c|}{ Percent disk area consumed when comparing } \\
\hline Conc. & Type & $\begin{array}{l}\text { Sucrose and } \\
\text { stlm, } A_{1}\end{array}$ & $\begin{array}{l}\text { Glucose and } \\
\text { stlm. } A_{2}\end{array}$ & $\begin{array}{l}\text { Fructose and } \\
\text { stim } A_{g}\end{array}$ \\
\hline$\overline{g(w / v)}$ & & mean $\pm \mathrm{SE}$ & mean $\neq \mathrm{SE}$ & mean $+S E$ \\
\hline 0.0 & Water & $0.1 \pm 0.0$ & $2.0 \pm 0.6$ & $1.8 \pm 0.5$ \\
\hline $\begin{array}{l}0.1 \\
0.1\end{array}$ & $\begin{array}{l}\text { Known sugar } \\
\text { Isolated stim. }\end{array}$ & $\begin{array}{l}11.9 \pm 1.9 \\
11.4 \pm 2.0\end{array}$ & $\begin{array}{l}19.8 * 3.0 \\
18.4 \pm 2.8\end{array}$ & $\begin{array}{l}5.6 \pm 1.2 \\
5,6 \pm 1.4\end{array}$ \\
\hline $\begin{array}{l}0.3 \\
0.3\end{array}$ & $\begin{array}{l}\text { Known sugar } \\
\text { Isolated stim. }\end{array}$ & $\begin{array}{l}20.9 \pm 2.5 \\
19.0 \pm 2.6\end{array}$ & $\begin{array}{l}29.7 \pm 4.3 \\
27.4 \pm 3.3\end{array}$ & $\begin{array}{l}13.8+3.1 \\
12.1+3.0\end{array}$ \\
\hline $\begin{array}{l}0.9 \\
0.9\end{array}$ & $\begin{array}{l}\text { Known sugar } \\
\text { Isolated stim. }\end{array}$ & $\begin{array}{l}30.9 \pm 4.7 \\
34.5 \pm 4.4\end{array}$ & $\begin{array}{l}30.9 \pm 2.5 \\
34.4 \pm 4.6\end{array}$ & $\begin{array}{l}30.2 \pm 3.8 \\
34.1 \pm 4.0\end{array}$ \\
\hline
\end{tabular}

sucrose at equal concentrations in the same bioassay feeding chamber, sucrose stimulated the greatest feeding at each of the three concentrations tested (Table 4). Disks treated with glucose and fructose were fed upon equally at all concentrations.

The reviews of Beck (5) and Thorsteinson (9) cite several instances in which sugars served as feeding stimulants for phytophagous insects. Although sugars may play a significant role in determining the resistance or susceptibility of plants to certain insects, it is unlikely that they are wholly responsible for the host specificity of the sweetclover weevil, whose feeding appears to be limited to certain species within the genera Melilotus, Trigonella, and Medicago. Other constituents of Melilotus leaves which influence sweetclover weevil feeding include unidentified chloroform-soluble feeding stimulant(s) (4), unidentified Deterrent $A$ (3) and Deterrent $B$ which has been identified as nitrate (2). A full understanding of the resistance and susceptibility of Melilotus plants to weevil feeding must take into account these constituents, and possibly others, as well as sucrose, glucose, and fructose.

\section{LITERATURE CITED}

1. Akeson, W. R., H. J. Gorz, F. A. Haskins. and G. R. Manglitz. 1968. A water-soluble factor in Melilotus officinalis leaves
Table 4. Comparison of sucrose, glucose, and fructose as sweetclover weevil feeding stimulants. Equal concentrations of the three sugars were assayed together in the same chamber with a population of three weevils per disk. Each comparison consisted of five disks per treatment, four treatments in each replication and four replications.

\begin{tabular}{|c|c|c|}
\hline \multicolumn{2}{|c|}{ Solution compared* } & \multirow{2}{*}{$\begin{array}{c}\% \text { disk area consumed, } \\
\text { mean } \pm \mathrm{SE}\end{array}$} \\
\hline Conc.. & Sugar & \\
\hline--- & Water & $4.4 \pm 1.7$ \\
\hline 0.9 & Sucrose & $43.9+4.4$ \\
\hline 0.9 & Glucose & $28,5+3.8$ \\
\hline 0.9 & Fructose & $29.6+3.8$ \\
\hline$\cdots$ & Water & $2.2 \pm 0.5$ \\
\hline 0.3 & Sucrose & $24.3+5.2$ \\
\hline 0.3 & Glucose & $17.3 \pm 3.7$ \\
\hline 0.3 & Fructose & $16.8 \pm 2.7$ \\
\hline -.. & Water & $3.0+1.1$ \\
\hline 0.1 & Sucrose & $15.4 \pm \mathbf{3 . 7}$ \\
\hline 0.1 & Glucose & $9.6+2.1$ \\
\hline 0.1 & Fructose & $9.9+1.1$ \\
\hline
\end{tabular}

A mixture of $0.1 \mathrm{ml}$ of the sugar solution
applied to the flve disks of each treatment.

which stimulates feeding by the adult sweetclover weevil. J. Econ. Entomol, 61:1111-1112.

2. Akeson, W. R., F. A. Haskins, and H. J. Gorz. 1969. Sweetclover-weevil feeding deterrent B: Isolation and identification. Science 163:293-294.

3. Akeson, W. R., F. A. Haskins, H. J. Gorz, and G. R. Manglitz. 1968. Water-soluble factors in Melilotus leaves which influence feeding by the sweetclover weevil. Crop Sci. 8:574-576.

4. Akeson, W. R., G. R. Manglitz, H. J. Gorz, and F. A. Haskins. 1967. A bioassay for detecting compounds which stimulate or deter feeding by the sweetclover weevil. J. Econ. Entomol. 60:1082-I084.

5. Beck, S. D. 1965. Resistance of plants to insects. Ann. Rev. Entomol. 10:207-232.

6. Hodge, J. E., and B. T. Hofreiter. 1962. Determination of reducing sugars and carbohydrates. p. 380-394. In $\mathrm{R}$. L. Whistler, and M. L. Wolfram (ed.) Methods in carbohydrate chemistry. Vol. I. Analysis and preparation of sugars. Academic Press, New York.

7. Manglitz, G. R., and H. J. Gorz. 1964. Host range studies with the sweetclover weevil and the sweetclover aphid. J. Econ. Ent. 57:683-687.

8. Randerath, K. 1966. Thin-layer chromatography. p. 236. Academic Press, New York.

9. Thorsteinson, A. J. 1960. Host selection of phytophagous insects, Ann. Rev. Ent. 5:193-218.

10. Waldi, D. 1965. Spray reagents for thin-layer chromatography. p. 483-502. In E. Stahl (ed.) Thin-layer chromatography - a laboratory handbook. Academic Press, New York. 